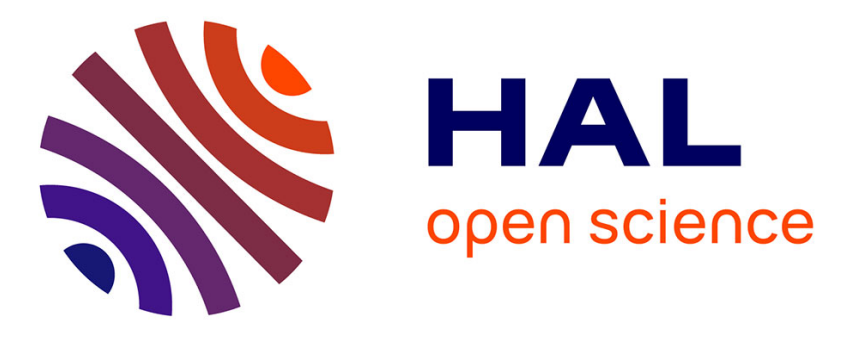

\title{
210 Po, an atmospheric tracer of long-range transport of volcanic plumes
}

\author{
Eun-Yun Nho, Marie-Françoise Le Cloarec, Bénédicte Ardouin, Michel
}

Ramonet

\section{- To cite this version:}

Eun-Yun Nho, Marie-Françoise Le Cloarec, Bénédicte Ardouin, Michel Ramonet. 210 Po, an atmospheric tracer of long-range transport of volcanic plumes. Tellus B - Chemical and Physical Meteorology, 1997, 49 (4), pp.429-438. 10.3402/tellusb.v49i4.15980 . hal-03115980

\section{HAL Id: hal-03115980 \\ https://hal.science/hal-03115980}

Submitted on 20 Jan 2021

HAL is a multi-disciplinary open access archive for the deposit and dissemination of scientific research documents, whether they are published or not. The documents may come from teaching and research institutions in France or abroad, or from public or private research centers.
L'archive ouverte pluridisciplinaire HAL, est destinée au dépôt et à la diffusion de documents scientifiques de niveau recherche, publiés ou non, émanant des établissements d'enseignement et de recherche français ou étrangers, des laboratoires publics ou privés. 


\section{Tellus B: Chemical and Physical Meteorology}

\section{${ }^{210} \mathrm{Po}$, an atmospheric tracer of long-range transport of volcanic plumes}

\section{Eun-Yun Nho, Marie-FrançOise Le Cloarec, BéNéDicte Ardouin \& Michel Ramonet}

To cite this article: Eun-Yun Nho, Marie-FrançOise Le Cloarec, BéNéDicte Ardouin \& Michel Ramonet (1997) ${ }^{210} \mathrm{Po}$, an atmospheric tracer of long-range transport of volcanic plumes, Tellus $\mathrm{B}$ : Chemical and Physical Meteorology, 49:4, 429-438, DOI: 10.3402/tellusb.v49i4.15980

To link to this article: https://doi.org/10.3402/tellusb.v49i4.15980

\section{(c) 1997 The Author(s). Published by Taylor \& Francis.}

\section{Published online: 18 Jan 2017.}

Submit your article to this journal

Џll Article views: 51

Q View related articles $\longleftarrow$

4 Citing articles: 6 View citing articles 


\title{
${ }^{210} \mathrm{Po}$, an atmospheric tracer of long-range transport of volcanic plumes
}

\author{
By EUN-YUN NHO, MARIE-FRANÇOISE LE CLOAREC*, BÉNÉDICTE ARDOUIN and \\ MICHEL RAMONET ${ }^{1}$, Centre des Faibles Radioactivités, Laboratoire mixte CNRS-CEA, Avenue de la \\ Terasse, 91190 Gif sur Yvette, France; ${ }^{1}$ Climate Monitoring and Diagnostics Laboratory, National Oceanic \\ and Atmospheric Administration, Boulder, CO, 80303 USA
}

(Manuscript received 19 February 1996; in final form 3 March 1997)

\begin{abstract}
With the aim of testing the ability of ${ }^{210}$ Po to be a tracer of volcanic aerosol plumes, we collected air samples during an oceanographic cruise around the Indonesian arc and measured the radioactivity of ${ }^{210} \mathrm{Po}$. Owing to the atmospheric circulation pattern and geographical distribution of ${ }^{210} \mathrm{Po}$ sources around the sampling site, the origin of ${ }^{210} \mathrm{Po}$ of the samples could be determined by calculating 5-day backward air mass trajectories. It is shown that the signature of ${ }^{210} \mathrm{Po}$ originating from volcanic emissions is distinct from that of ${ }^{222} \mathrm{Rn}$ decay, even though these processes are the 2 major sources of atmospheric ${ }^{210} \mathrm{Po}$. Moreover, the proportion of ${ }^{210} \mathrm{Po}$ in a given air parcel is conservative during the transport: as other aerosols, ${ }^{210} \mathrm{Po}$ aerosols are very sensitive to the atmospheric removal processes and the production and the loss of ${ }^{210}$ Po by radio decay within an air parcel is negligible. Our results confirm that ${ }^{210}$ Po is a good tracer for aerosols emitted by volcanoes.
\end{abstract}

\section{Introduction}

Volcanic activity has long been recognized as causing significant changes of the Earth's environment. As human activities do, volcanic emissions are also capable of altering the chemical composition of the atmosphere which could thereby induce modifications on climate as well as on biogeochemical cycles of our planet. Indeed, volcanoes are likely to be one of the major natural sources of trace elements in the atmosphere.

In order to foresee the consequence of volcanic emissions, studies not only on the volcanic source strength but also on their atmospheric transport should be made. However, the trace elements injected into the atmosphere by volcanic emissions are also emitted by various other sources and

\footnotetext{
* Corresponding author; e-mail: Marie-Francoise. Le-Cloarec@cfr.cnrs-gif.fr
}

their diffusion in the atmosphere and their removal from it, are still largely unknown. Tracer studies may be helpful to solve these questions of emission budget and atmospheric transport.

${ }^{210} \mathrm{Po}$, the last radioactive nuclide of the ${ }^{238} \mathrm{U} /{ }^{226} \mathrm{Ra}$ series, is one of the characteristic chemical species emitted by a magma. Volcanoes were shown to be one of the major source of ${ }^{210} \mathrm{Po}$ in the atmosphere, the other one being the decay of atmospheric ${ }^{222} \mathrm{Rn}$ emitted everywhere by soils. This radionuclide is very volatile at high temperature (above $400^{\circ} \mathrm{C}$ ) and is therefore found to be considerably enriched in volcanic plumes. Moreover, the ${ }^{210} \mathrm{Po}$ is emitted in the gaseous phase, then immediately transformed into particles by a gas-to-particle conversion process in volcanic plumes which leads to particles small enough to be transported on long distance. We propose here to show that this enrichment can be used to specifically trace volcanic sources to simulate 
atmospheric transport and dispersion of natural sources.

To examine the ability of the ${ }^{210} \mathrm{Po}$ to be a tracer of volcanic aerosols, air samples were collected around the Indonesian arc, one of the most active volcanic areas in the world (Simkin et al., 1981), during the Campaign JADE II (March, 1992) and measured for the radioactivity of ${ }^{210} \mathrm{Po}$. The contribution of different sources of ${ }^{210} \mathrm{Po}$ in each sample is firstly assessed by referring to their 5-day backward air mass trajectories and the meteorological conditions observed during the sampling. The magnitude of ${ }^{210} \mathrm{Po}$ signal is then discussed according to its source origin.

\section{Sampling and analysis}

Nineteen air samples were collected on board the French research vessel "Marion Dufresne", around the Indonesian arc during the Campaign JADE II, from 1 March to 23 March (Table 1). The navigation track of the sampling ship and its environment are shown on Fig. 1. Meteorological parameters, such as air temperature, atmospheric pressure, wind direction, rain events, etc. were also made on board all along the cruise. The occurrence of squalls and rain are given in Table 1.

The air was filtered using cellulose filters, during about $24 \mathrm{~h}$ for each sample, at a flow rate of $12 \mathrm{~m}^{3}$ $\mathrm{h}^{-1}$. To avoid a possible contamination by the ship exhaust, the sampler was positioned in the forward part of the ship. The collected samples were directly used without any further preparation to measure the ${ }^{210} \mathrm{Po}$ activity by counting the gross alpha activity with a silver activated zinc sulfide scintillator. Details of their gross alpha measurements, the counting efficiency, calibration method of the counter and the calculation of ${ }^{210} \mathrm{Po}$ activities at the time of sampling are given in Nho et al. (1996a).

\section{Results and discussion}

The measured ${ }^{210} \mathrm{Po}$ activity of the nineteen samples are listed in Table 2. Their activities range from 1.2 to $66 \mu \mathrm{Bq} \mathrm{m} ~ m^{-3}$ which appear to be somewhat lower than those observed in surface air over continent in northern hemisphere (Winkler et al., 1981; Carvalho, 1995). This is due to the environment of the sampling location: over the ocean in the southern hemisphere where land mass, the eventual source of ${ }^{210} \mathrm{Po}$, is smaller than that in the northern hemisphere.

The observed wide sample-to-sample variation in ${ }^{210} \mathrm{Po}$ activities reflects the origin and the history of the relevant air masses. To interpret more precisely the measurements and to detect the influence of volcanoes, we studied possible sources of ${ }^{210} \mathrm{Po}$ around the sampling site and examined the air mass origins of the samples by 5-day backward air mass trajectories.

\subsection{Sources of atmospheric ${ }^{210} \mathrm{Po}$}

The ${ }^{210} \mathrm{Po}$ is a natural radionuclide belonging to the ${ }^{238} \mathrm{U}$ decay chain.

$$
\begin{aligned}
{ }^{238} \mathrm{U} \rightarrow{ }^{226} \mathrm{Ra} \rightarrow & { }^{222} \mathrm{Rn} \rightarrow \text { (short-lived products) } \\
& 3.8 \mathrm{~d} \\
& \rightarrow{ }^{210} \mathrm{~Pb} \rightarrow{ }^{210} \mathrm{Bi} \rightarrow{ }^{210} \mathrm{Po} \\
& 22 \mathrm{y} \quad 5 \mathrm{~d} \quad 138 \mathrm{~d} \\
& \rightarrow{ }^{206} \mathrm{~Pb} \text { (stable) }
\end{aligned}
$$

The global emission of ${ }^{210} \mathrm{Po}$ to the atmosphere is about $3.5 \cdot 10^{15} \mathrm{~Bq} \mathrm{yr}^{-1}$ (Lambert et al., 1982). One third of this emission is accounted for by the radioactive decay of ${ }^{210} \mathrm{~Pb}$ (Lambert et al., 1982), derived from the atmospheric ${ }^{222} \mathrm{Rn}$. As this noble gas is emanated from ${ }^{226} \mathrm{Ra}$ decay which is rather uniformly distributed in the continental crust, then diffuses into the atmosphere (Wilkening et al., 1972; Turekian et al., 1977), the ${ }^{210}$ Po resulting from the atmospheric ${ }^{222} \mathrm{Rn}$ decay is distributed in a relatively homogeneous way over continents.

Other sources of atmospheric ${ }^{210} \mathrm{Po}$ have been discussed by several authors: volcanoes, biomass burning, soil dusts, etc.

Lambert et al. (1982) showed that volcanic emissions inject directly this nuclide into the atmosphere and provide nearly as much ${ }^{210} \mathrm{Po}$ as the decay of atmospheric ${ }^{222} \mathrm{Rn}$. Furthermore, Nho et al. (1996b) estimated that the flux of ${ }^{210} \mathrm{Po}$ emitted from the volcanoes in the Indonesian arc represents about $15 \%$ of its global volcanic flux.

The emission of ${ }^{210} \mathrm{Po}$ from savanna burning was estimated by Le Cloarec et al. (1995); it accounts for about $10 \%$ of the global production of atmospheric ${ }^{210} \mathrm{Po}$. However, the amount of biomass burnt in tropical Asia and in Australia is 


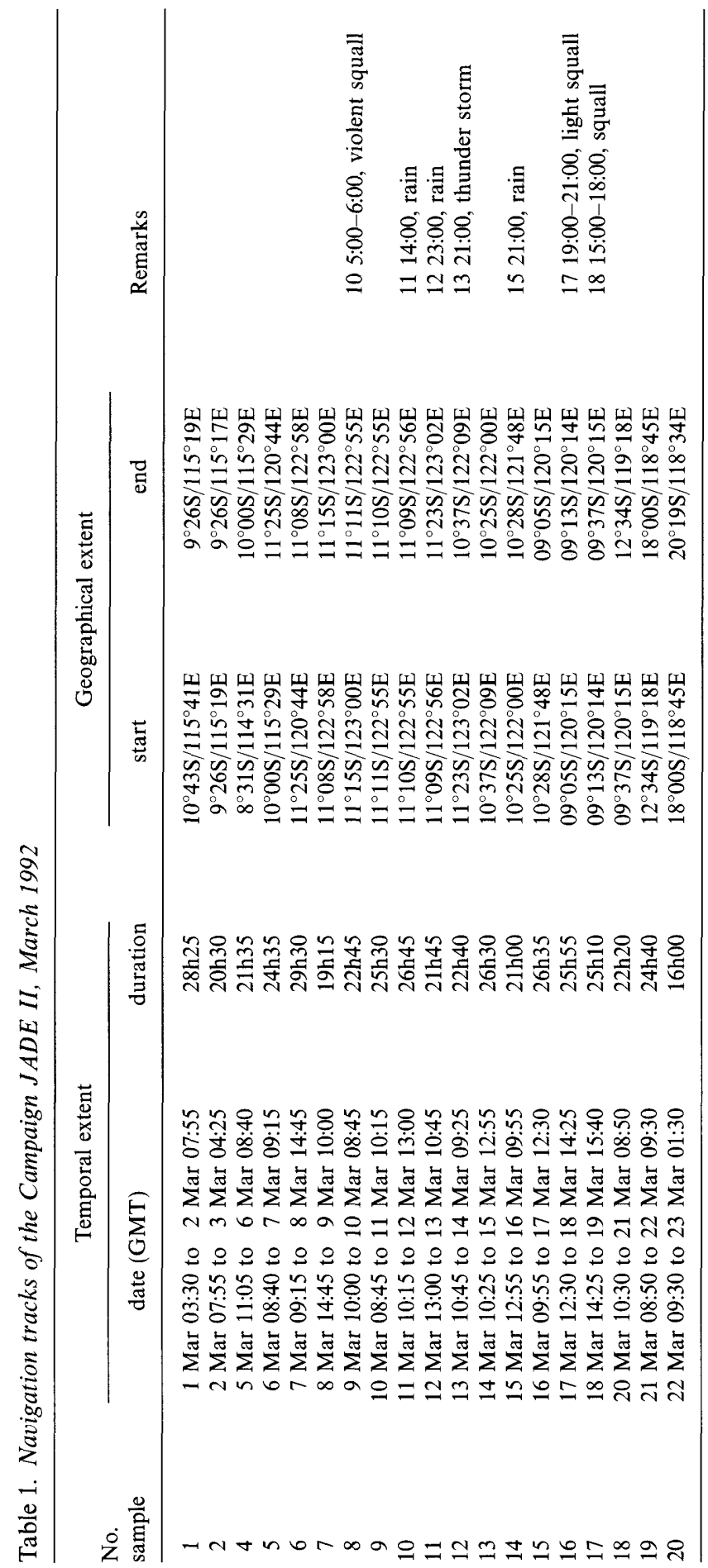




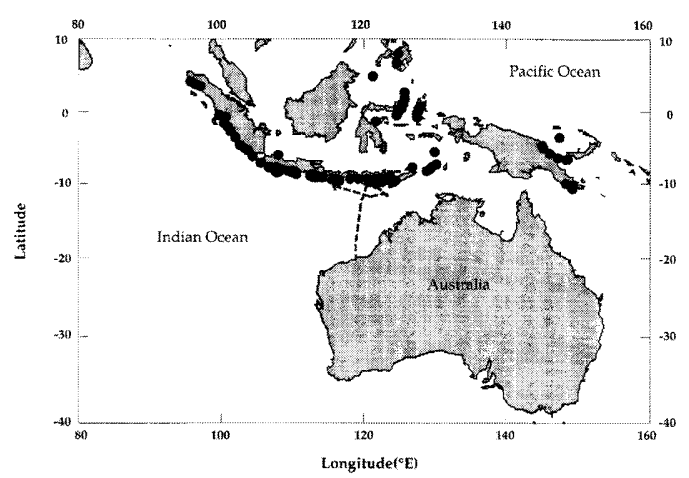

Fig. 1. Navigation track of the sampling ship (---) and location of the volcanoes in the Indonesian Arc (•).

Table 2. ${ }^{210} \mathrm{Po}$ and ${ }^{210} \mathrm{~Pb}$ activities of the samples collected around the Indonesian arc during the campaign JADE II, March 1992

\begin{tabular}{ccc}
\hline $\begin{array}{c}\text { No. } \\
\text { sample }\end{array}$ & $\begin{array}{c}{ }^{210} \mathrm{Po} \\
\left(\mu \mathrm{Bq} / \mathrm{m}^{3}\right)\end{array}$ & $\begin{array}{c}{ }^{210} \mathrm{~Pb} \\
\left(\mu \mathrm{Bq} / \mathrm{m}^{3}\right)\end{array}$ \\
\hline 1 & 12 & 513 \\
2 & 66 & 407 \\
4 & 36 & 290 \\
5 & 44 & 198 \\
6 & 5.1 & 259 \\
7 & 27 & 289 \\
8 & 7.3 & 214 \\
9 & 14 & 245 \\
10 & 8.8 & 363 \\
11 & 12 & 351 \\
12 & 14 & 214 \\
13 & 13 & 157 \\
14 & 7.1 & 364 \\
15 & 19 & 340 \\
16 & 51 & 268 \\
17 & 59 & 248 \\
18 & 36 & 529 \\
19 & 6.0 & 591 \\
20 & 1.2 & 391 \\
\hline
\end{tabular}

small compared to that in tropical Africa and America; moreover, the period of the most intensive burning usually occurs from June to September in the southern hemisphere (Hao et al., 1990). The contribution of this source appears therefore to be negligible at least around the sampling site in March.

Soil dusts resuspended from continental surface appear to be an important source of atmospheric ${ }^{210} \mathrm{Po}$ particularly in the lower atmospheric layers over continents but its proportion in the worldwide budget is not well known (Moore et al., 1980; Carvalho, 1995; Nho et al., 1996). In the sampling site described here, soil dusts may be derived from the Eurasian continent and Australian desert. However, due to the characteristic atmospheric circulation pattern around the sampling site in March (characterized by the Intertropical Convergence Zone, ITCZ, as discussed later), the influence of the soil dusts from the Eurasian continent can be ruled out. Additional contributions can arise from marine aerosols, due to ${ }^{210} \mathrm{Po}$ enriched surface waters resulting from biochemical activities. But their contribution is found insignificant (Turekian and Cochran, 1981; Turekian et al., 1989). Emissions from fossil fuel combustion have been studied by Marenco and Fontan (1972), who concluded that the contribution of this source is negligible.

\subsection{Air mass origins of the samples}

During the sampling season (March), the Indonesian arc, along which most volcanoes are localized, is generally out of the influence of the air masses from the Eurasian continent since Northeast trades are weaken and the ITCZ located along the Indonesian arc during the boreal winter tends to move toward to the north. This discontinuity between the stream from the Northern Hemisphere and that from the Southern Hemisphere is usually established along the Java Sea in March (Flores and Balagot, 1969). Moreover, the small area of the Indonesian arc does not emanate significant amount of ${ }^{222} \mathrm{Rn}$, the grandmother nuclide of ${ }^{210} \mathrm{Po}$. Thus, air masses arriving at the sampling site should have either a continental origin from the Australian continent, or a volcanic origin from the Indonesian arc, or oceanic origin, or their consecutive mixture.

In order to analyse the origins of ${ }^{210} \mathrm{Po}$ in the samples, 5-day backward air mass trajectories were calculated. Backward trajectories describe the pathway of an air parcel backward in time from the receptor point to potential source regions. They are calculated with a transport model using horizontal and vertical wind fields. For that purpose, we used a three-dimensional atmospheric transport model (TM2Z) which solves the mass conservation equation for the concentration of a tracer on an Eulerian grid with $2.5^{\circ} \times 2.5^{\circ}$ reso- 
lution in the horizontal and 9 layers in vertical extending from the surface to $10 \mathrm{hPa}$ along a sigma coordinate (Heimann and Keeling, 1989, Ramonet et al., 1996). The 4 lowest layers extend approximately to $400,1200,2600$ and $4700 \mathrm{~m}$, respectively, above the sea surface.

The principle consists in injecting a given quantity of a conservative tracer in the grid cell corresponding to the location where the trajectory ends up. The conservative tracer is emitted in an homogeneous way and we calculate its dispersion during five days under the influence of inverted horizontal and vertical wind fields. Contrary to the classical single trajectory methods which supposes an hypothetical infinitesimally small parcel, the method used here calculates the retro-dispersion of an air mass and thus gives an information not only on the main trajectory but also on secondary origins (retro-dispersion plume) (Ramonet et al., 1996). However, as for other backward trajectory methods, convective transport is neglected, which may lead to underestimate the vertical mixing (Ramonet, 1994). The wind fields used to run the model were deduced from observations and analysed at the European Centre for Medium-Range Weather Forecast (ECMWF). Wind fields are updated every 12 hours but the model calculates the tracer concentration at each one-hour time step. The limitations of air trajectory models regarding their use in interpreting atmospheric chemistry measurements were well reviewed by Kahl (1993).

As shown in Table 1, the samples were collected over two days with an average duration of about $24 \mathrm{~h}$, beginning in the morning and finishing in the next morning. The distance travelled during sample collection is quite variable and the longest one spreads over 3 grid boxes of the model. Taking into account this spatial and temporal extension of the sampling, 6 trajectories were calculated for each sample. Trajectories were calculated at 3 points: at 1200GMT (day 1), 0000GMT and 1200GMT (day 2) corresponding to the starting, middle and end point, respectively, of the geographical track of the sampling. Furthermore, the trajectories were calculated at two model levels, the lower at $894 \mathrm{hPa}$ in the planetary boundary layer and the higher at $635 \mathrm{hPa}$ in the free troposphere in order to take into account the altitude of the volcanoes, which ranges from the surface to $3800 \mathrm{~m}$.
For a given sample, origin and distance of trajectories are not significantly different at the three points within a given model level if geographical distribution of ${ }^{210} \mathrm{Po}$ sources is considered. But the distance of the trajectory is usually longer in the higher model level than that in the lower one, reflecting stronger wind velocity in higher altitude. In some cases, the direction of trajectories is observed notably different in the two model levels (samples nos. 12 and 13).

Furthermore, as the trajectory model could not give informations on atmospheric scavenging, meteorological observations during the sampling were taken into account. Three samples which experienced short rain events during their collection (samples nos. 10, 11 and 14 ) show very low ${ }^{210} \mathrm{Po}$ activities, meaning that ${ }^{210} \mathrm{Po}$ is very efficiently removed from the atmosphere by washout. Indeed ${ }^{210} \mathrm{Po}$ is either derived from atmospheric ${ }^{210} \mathrm{~Pb}$ decay or injected directly into the atmosphere. As ${ }^{210} \mathrm{Po}$ and its precursor are in particulate phase, washout by rainfall results in a strong lowering of their concentration. It can be pointed out that the recover of ${ }^{210} \mathrm{Po}$ content within an air parcel takes at least several months because the long half-life of ${ }^{210} \mathrm{~Pb}$ prevents the growth of ${ }^{210} \mathrm{Po}$ from ${ }^{222} \mathrm{Rn}$ decay.

The impact of squall on the ${ }^{210} \mathrm{Po}$ activities in the air is not so clear (samples nos. 8, 16 and 17). In fact the squalls can affect the ${ }^{210}$ Po concentrations through 2 processes: (1) precipitation frequently accompanies violent squalls (Hastenrath, 1994 ) and then can induce a washout of ${ }^{210} \mathrm{Po}$ as well as of its precursor; (2) wind speed increases during the squall which results in a higher efficiency of dry deposition (Twomey, 1977). From our measurements it appears that violent squalls resulted in low activity of the nuclide but mild and light ones appear to have no influence. For the sample no. 8 whose ${ }^{210} \mathrm{Po}$ activity is low $\left(7.3 \mu \mathrm{Bq} \mathrm{m}^{-3}\right)$, the air masses seem to have experienced either wet deposition not far away from the sampling site, or dry deposition due to high wind speed $\left(20.4 \mathrm{~m} \mathrm{~s}^{-1}\right)$. On the contrary the other two samples (nos. 16 and 17) which experienced mild and light squall events (wind speeds were $8 \mathrm{~m} \mathrm{~s}^{-1}$ and $7 \mathrm{~m} \mathrm{~s}^{-1}$, respectively) have relatively high ${ }^{210} \mathrm{Po}$ activities $\left(51.1\right.$ and $58.9 \mu \mathrm{Bq} \mathrm{m}^{-3}$, respectively) which means that they did not undergo wet deposition.

We have classified the samples into 3 groups 
according to the trajectories of the corresponding air masses (Table 3). The air masses of the first group come from the Australian continent, then travel over ocean and arrive at the sampling site. The second group involves the air masses which spent most of their time over the Indonesian arc. In the third group, air masses have mixed origins, travelling first from the Australian continent via ocean and then passing above volcanic regions. A typical air mass trajectory of each group is shown in Fig. 2.

\section{3. ${ }^{210}$ Po activities versus air mass origin}

In Fig. 3, the ${ }^{210}$ Po activities of the air samples are presented according to their air mass origin.

The air samples having a continental origin show indiscriminately very low ${ }^{210} \mathrm{Po}$ activity $\left(5 \mu \mathrm{Bq} \mathrm{m} \mathrm{m}^{-3}\right)$. This may be explained by the fact that the continental air masses are diluted during the transport toward over the ocean without any supplementary sources. However, we cannot rule out the possibility that the low ${ }^{210} \mathrm{Po}$ activity of air masses is due to washing out during the transport before arriving at the sampling site. To examine this, we measured the ${ }^{210} \mathrm{~Pb}$ activity on the filters because this nuclide is also present in the particulate phase in the atmosphere and the continental surface is its principal source (Table 2) (Lambert et al., 1982; Carvalho, 1995).

In all samples, ${ }^{210} \mathrm{~Pb}$ activities are much higher than those of ${ }^{210} \mathrm{Po}$, indicating that ${ }^{210} \mathrm{~Pb}$ is continuously produced in the atmosphere from the decay of ${ }^{222} \mathrm{Rn}$ whereas the short aerosols residence time (about 7 days) prevents the growth of

Table 3. Air mass origin of the samples, deduced from 5-day backward trajectories

\begin{tabular}{ll}
\hline Air mass origin & No. sample \\
\hline
\end{tabular}

\section{Australian continent}

- without rainfall events

$6,19,20$

II. Volcanic region

-without rainfall events

- with rainfall events

$4,16,17,18$

9,10

III. Mixture of the two origins

- without rainfall events

- with rainfall events

$1,2,5,7,12,13,15$

$8,11,14$
${ }^{210} \mathrm{Po}$ from its parent, ${ }^{210} \mathrm{~Pb}$. Air masses derived from volcanoes (samples nos. 4, 16, 17 and 18) show relatively high ${ }^{210} \mathrm{~Pb}$ activity due to the local enrichment in ${ }^{210} \mathrm{~Pb}$ of volcanic plumes (Polian and Lambert, 1979).

As continental air masses (samples nos. 6, 19 and 20) retain still rather high ${ }^{210} \mathrm{~Pb}$ activity, we conclude that they have not experienced scavenging processes. In fact, ${ }^{210} \mathrm{~Pb}$ content may be partly recovered after scavenging processes within an air parcel from the decay of its mother nuclide, ${ }^{222} \mathrm{Rn}$ (3.8 days); during 5 days assuming that the wet deposition occurs at the very beginning of the air mass travel, only $0.03 \%$ of the initial activity of ${ }^{222} \mathrm{Rn}$ is recovered by this process. Then it cannot explain the high ${ }^{210} \mathrm{~Pb}$ activity of the continental air masses. In addition, taking into account the residence time of aerosols in the lower atmosphere (Balkanski et al., 1993), the expected ${ }^{210} \mathrm{Po} /{ }^{210} \mathrm{~Pb}$ ratio can be calculated (Burton and Stewart, 1960). From the low ${ }^{210} \mathrm{Po} /{ }^{210} \mathrm{~Pb}$ ratio (about 0.01 ), contamination by sources other than the decay of atmospheric ${ }^{222} \mathrm{Rn}$, for example, soil dusts or marine aerosols, could be neglected.

On the other hand, ${ }^{210} \mathrm{Po}$ activities of the air masses belonging to the second group, with a volcanic origin, can be divided into two parts: the higher one with activities ranging between 35 and $59 \mu \mathrm{Bq} \mathrm{m} \mathrm{m}^{-3}$ and the lower one with activities ranging from 9 to $14 \mu \mathrm{Bq} \mathrm{m} \mathrm{m}^{-3}$. The lower part includes two samples collected in sequence (sample nos. 9 and 10). The low ${ }^{210}$ Po activity of sample no. 10 is attributed to the wet deposition since rain events were observed on board during its collection. There is also a high probability that sample no. 9 was also affected by this scavenging process even though rain events were not observed on board: indeed this sample was collected successively in time and space between the two samples which experienced washout by rainfalls or violent squalls (sample nos. 8 and 10).

The ${ }^{210} \mathrm{Po}$ activity of the samples belonging to the third group is more variable than in the first two groups. Among them, the three samples affected by the atmospheric removal process (sample nos. 8, 11 and 14) have still very low activity values, about $9 \mu \mathrm{Bq} \mathrm{m} \mathrm{m}^{-3}$. The others, however, showed an activity range from 12 to $66 \mu \mathrm{Bq} \mathrm{m}^{-3}$. It is interesting to note that the highest ${ }^{210} \mathrm{Po}$ activity value was observed in this group $(66 \mu \mathrm{Bq}$ $\mathrm{m}^{-3}$ for the sample no. 2). The air mass collected 
on this sample travels from the West Australia via the Indian Ocean and the East Java. This trajectory is different from those of most other samples of this group (they usually begin in the Northeast Australia and pass the Lesser Sunda Islands region). The high activity is probably due to the noticeable volcanic activity in the East Java region when our sampling was made, because the emission rate of the ${ }^{210} \mathrm{Po}$ from a volcano is closely related to its volcanic activity (Bennet et al., 1982; Le Guern, 1982; Le Cloarec et al., 1994). Merapi $\left(7.54^{\circ} \mathrm{S}, 110.44^{\circ} \mathrm{E}\right.$, East Java), one of the most active volcanoes in the world, was in a phase of eruptive activity in March 1992 with an alert level 1 (Simkin et al., 1981; Smithsonian Institution, 1992a). The activity began at the end of January 1992, reaching a maximum during February requiring an alert level 3 and then lowered in March. Moreover the Semeru volcano was also in eruptive activity phase at the time of our sampling $\left(8.07^{\circ} \mathrm{S}, 112.55^{\circ} \mathrm{E}\right.$, East Java). This volcano was in a quasi-continuous eruptive activity phase since 1967 showing an average Volcanic Explosivity Index (VEI) of 2 or 3 (Smithsonian Institution, 1992b; Volcanological Society of Japan, 1994).

The trajectories of the sample no. 1 are similar to those of the sample no. 2 but trajectories approach more and more toward Java from sample no. 1 to sample no. 2 . We therefore attribute the high ${ }^{210} \mathrm{Po}$ activity of the sample no. 2 to the path of the air masses which encountered volcanic plumes emitted from these eruptive volcanoes.

These results show that the influence of the air mass origin on the ${ }^{210} \mathrm{Po}$ activities is quite clear and large differences in ${ }^{210} \mathrm{Po}$ activities are found even between the air masses originated from its two major sources, continental and volcanic, which have nearly the same weight in its global budget. This is likely due to the different emission mode of the two sources. The ${ }^{222} \mathrm{Rn}$, the continental source of ${ }^{210} \mathrm{Po}$, is emanated rather uniformly over continents (Wilkening et al., 1972; Turekian et al., 1977) and diffuses into the atmosphere owing to its gaseous nature. On the contrary, volcanic emissions of ${ }^{210} \mathrm{Po}$ can be considered as point sources both in time and space. Therefore, even though the two sources have about the same weight in the global budget, the ${ }^{210} \mathrm{Po}$ magnitude of their signature is very different. These character- istics of the two ${ }^{210}$ Po major sources were used in our analysis and make feasible the use of ${ }^{210} \mathrm{Po}$ as a tracer of volcanic plumes.

\section{Conclusions}

An attempt was made to develop an atmospheric tracer of volcanic aerosols based on empirical measurements in the distance from the sources and determining the source origins by air mass trajectories.

Owing to the favorable geographical distribution of ${ }^{210} \mathrm{Po}$ sources and atmospheric circulation patterns around the Indonesian arc during the sampling season, origins of the sampled air masses could be assessed and the samples could be classified according to the ${ }^{210}$ Po sources.

The following points could be emphasized.

(1) The volcano-derived ${ }^{210} \mathrm{Po}$ signatures are still eminent in the distance from the sources. This is probably due to the different emission mode of the two major sources of ${ }^{210} \mathrm{Po}$, volcanic source and continental source: one is sporadic and the other is rather steady.

(2) Irrespective to its origin, the ${ }^{210} \mathrm{Po}$ in the air is very sensitive to the atmospheric removal processes. This is explained by first, the particulate nature of ${ }^{210} \mathrm{Po}$ and of its precursor, ${ }^{210} \mathrm{~Pb}$ and second, the long half-life of ${ }^{210} \mathrm{~Pb}$ between ${ }^{222} \mathrm{Rn}$ and ${ }^{210} \mathrm{Po}$ in the ${ }^{238} \mathrm{U}$ family which prevents the growth of ${ }^{210} \mathrm{Po}$ within an air parcel.

(3) The study demonstrates clearly that ${ }^{210} \mathrm{Po}$ can meet the requirements to be a tracer of volcanic aerosols: it is largely volcano-derived, sampled and measured accurately and not affected by chemical transformation during the transport. Particularly, the identification of ${ }^{210} \mathrm{Po}$ pulses emitted from volcanoes in remote areas is relatively easy as well as the source location with the use of air mass trajectories.

Predicted applications of these results might include studies on the long-range diffusion of volcanic plumes. The estimation of the impact of volcanic emissions at remote sites could be done by means of an atmospheric transport model to trace elements injected into the atmosphere from volcanoes, for example, sulfur dioxide and metals, using the ${ }^{210} \mathrm{Po}$ as a tracer. Namely, for a given time and space, the atmospheric concentrations of the trace elements originated from volcanic 

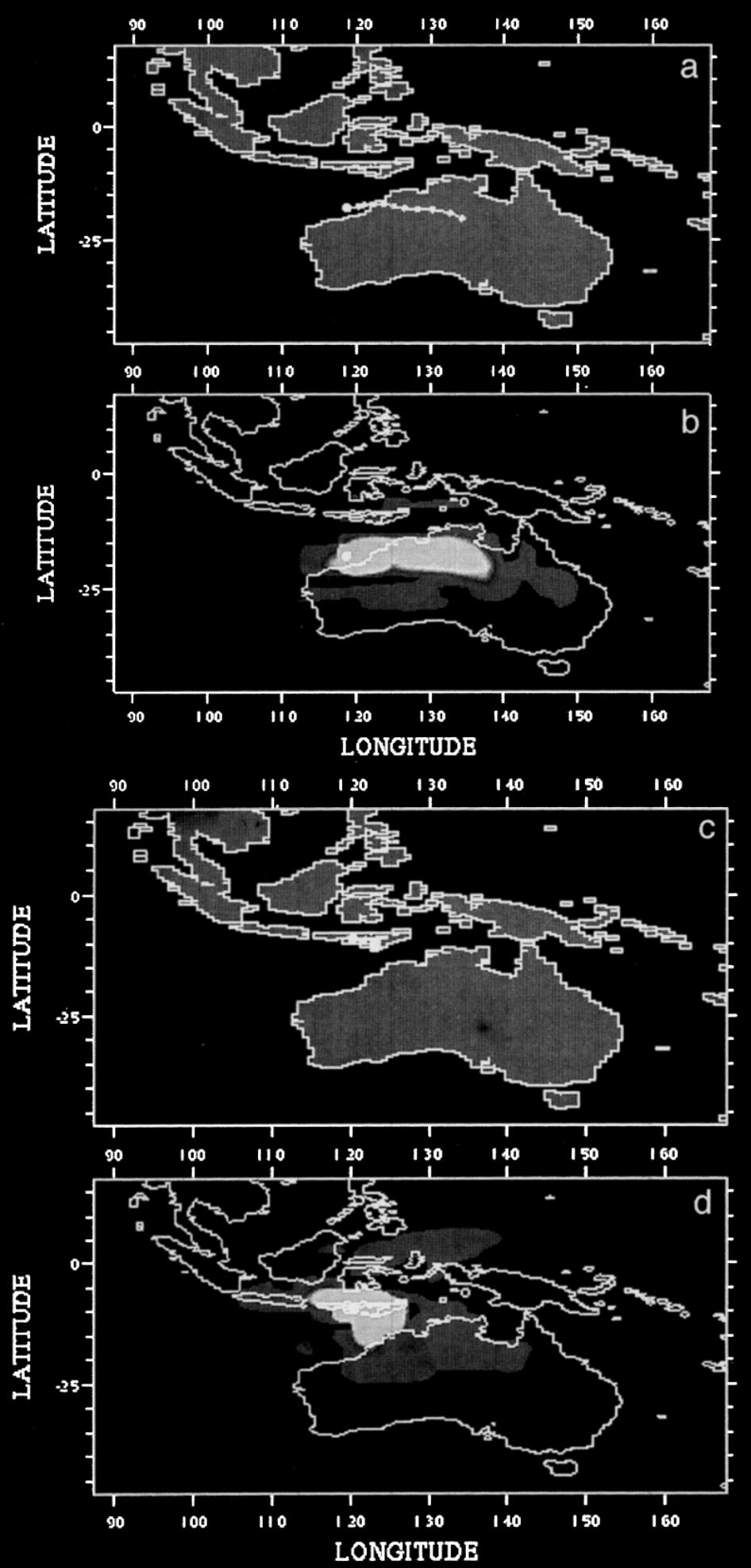

Fig. 2. 


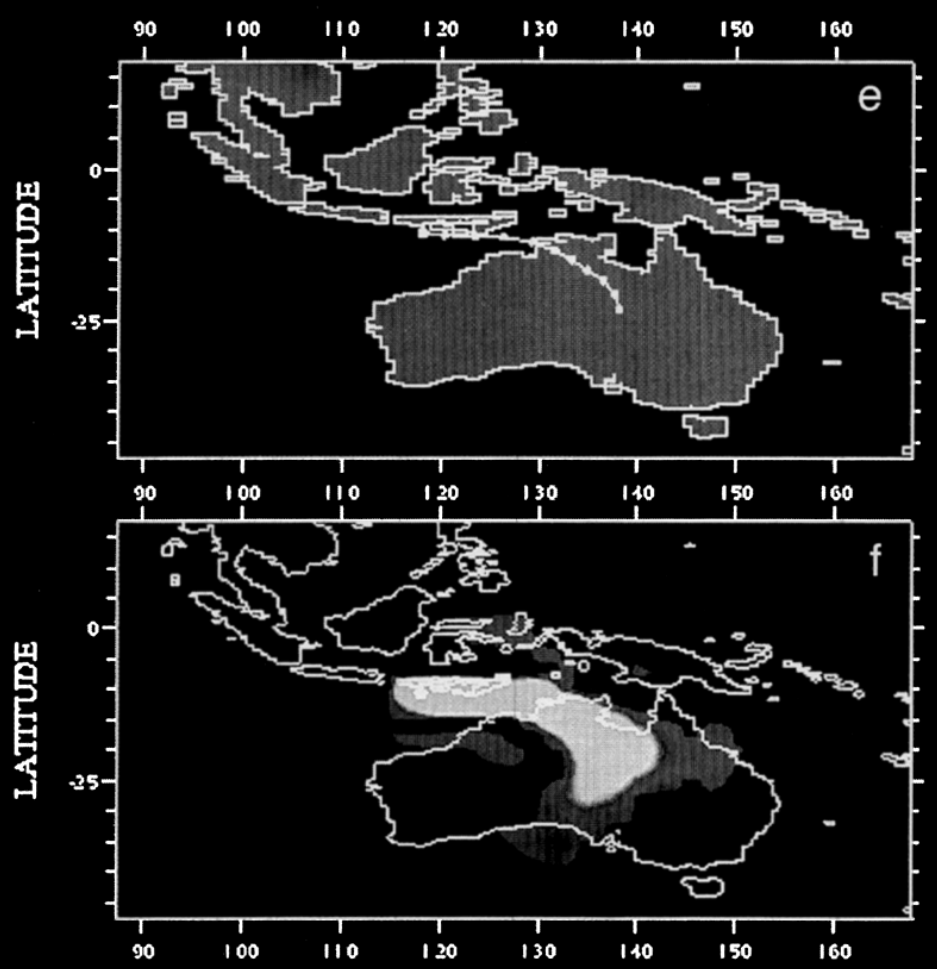

Fig. 2 (cont'd). Typical 5-day backward trajectories for each air mass origin group. (a) and (b) for continental origin (sample no. 19), (c) and (d) for volcanic origin (sample no. 16) < and (e) and (f) for mixed origin (sample no. 5). (a), (c), and (e) show the main trajectories, and (b), (d), and (f) show the retro-dispersion plumes accumulated during 5 days.

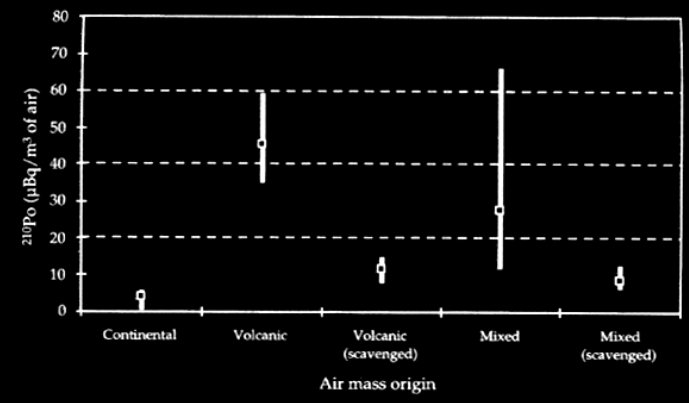

Fig. 3. Variation of the ${ }^{210} \mathrm{Po}$ activity of the samples according to their air mass origin. $\square$ shows mean value and $\mid$ represents maximum and minimum values. sources could be deduced with the knowledge on ${ }^{210} \mathrm{Po}$ and its associated trace element fluxes at the volcanic source and the parametrization on transport behaviour of the aerosols carrying ${ }^{210} \mathrm{Po}$ and trace elements.

\section{Acknowledgements}

The authors are grateful to Michèle Fieux (Laboratoire d'Océanographie Dynamique et de Climatologie) for her valuable participation on aerosol sampling during the campaign Jade II. They appreciate also helpful comments of François Dulac. This work was financially supported by CIFEG (French Department of Environment), CFR 1944. 


\section{REFERENCES}

Balkanski, Y. J., Jacob, D. J. and Gardner, G. M. 1993. Transport and residence times of continental aerosols inferred from a global three-dimensional simulation of ${ }^{210}$ Pb. J. Geophys. Res. 98, 20573-20586.

Bennet, J. J., Krishnaswami, S., Turekian, K. K., Melson, M. G. and Hopson, C. A. 1982. The Uranium and Thorium decay series nuclides in Mount St. Helens effusives. Earth Planet. Sci. Lett. 60, 60-69.

Burton, R. D. and Stewart, N. G. 1960. Use of long-lived natural radioactivity as an atmospheric tracer. Nature 186, 584-589.

Carvalho, F. P. 1995. Origins and concentrations of ${ }^{222} \mathrm{Rn},{ }^{210} \mathrm{~Pb},{ }^{210} \mathrm{Bi}$ and ${ }^{210} \mathrm{Po}$ in the surface air at Lisbon, Portugal, at the Atlantic edge of the European Continental Landmass. Atmospheric Environment 29, 1809-1819.

Flores, J. F. and Balagot, V. F. 1969. Climate of Philippines. Climates of Northern and Eastern Asia, in World Survey of Climatology, vol. 8, (ed. Arakawa, H.). Elsevier, Amsterdam, 159-213.

Hao, W. M., Liu, M. H. and Crutzen, P. J. 1990. Estimates of annual and regional releases of $\mathrm{CO}_{2}$ and other trace gases to the atmosphere from fires in the tropics, based on the FAO statistics for the period 1975-1980. Fire in the tropical biota: ecosystem processes and global challenges, (ed. Goldammer, J. C.). Ecological studies 84, Springer-Verlag, Berlin-Heidelberg, 440-462.

Hastenrath, S. 1994. Climate dynamics of the tropics. Kluwer Academic Publishers, Dordrecht, 182-197.

Heimann, M. and Keeling, C. D. 1989. A threedimensional model of atmospheric $\mathrm{CO}_{2}$ transport based on observed winds (2). model description and simulated tracer experiments. Geophys. Mono. 55, 237-275.

Kahl, J. D., 1993. A cautionary note on the use of air trajectories in interpreting atmospheric chemistry measurements. Atmospheric Environment 27 3037-3038.

Lambert, G., Polian, G., Sanak, J., Ardouin, B., Jegou, A. and Le Roulley, J. C. 1982. Cycle du radon et de ses descendants: application à l'étude des échanges troposphère-stratosphère. Ann. Geophys. 38, 497-531.

Le Cloarec, M. F., Ardouin, B., Cachier, H., Liousse, C., Neveu, S. and Nho, E. Y. 1995. ${ }^{210} \mathrm{Po}$ in savanna burning plumes. J. Atmos. Chem. 22, 111-122.

Le Cloarec, M. F., Pennisi, M., Corazza, E. and Lambert, G. 1994. Origin of fumarolic fluids emitted from a non-erupting volcano: radionuclide constraints at Vulcano (Aeolian Islands, Italy). Geochim. Cosmochim. Acta 58, 4401-4410.

Le Guern, F., Le Roulley, J. C. and Lambert, G. 1982. Condensation du Polonium dans les gaz volcaniques. Compte Rendu Acad. Sci. Paris 294, 887-890.

Marenco, A. and Fontan, J. 1972. Sources of polonium 210 within the troposphere. Tellus 24, 38-46.
Moore, H. E., Poet, S. E. and Martell, E. A. 1980. Size distribution and origin of lead-210, bismuth-210 and polonium-210 on airborne particles in the troposphere. The natural radiation environment (III), (ed. Gesell T. F. and Lowder W. M.). Technical Information Center, U. S. Department of Energy, Springfield, Virginia. 281-293.

Nho, E. Y., Le Cloarec, M. F., Ardouin, B. and Ramonet, M. 1996a. Origins of ${ }^{210} \mathrm{Po}$ in the atmosphere at Lamto, Ivory Coast: Biomass burning and Saharan dusts. Atmospheric Environment 30, 3705-3714.

Nho, E. Y., Le Cloarec, M. F., Ardouin, B. and Tjetjep, W. S. 1996b. Source strength assessment of volcanic trace elements emitted from the Indonesian arc. $J$. Volcanol. Geotherm. Res. 74, 121-129.

Polian, G. and Lambert, G. 1979. Radon daughters and sulfur output from Erebus volcano, Antarctica. J. Volcanol. Geotherm. Res. 6, 125-137.

Ramonet, M. 1994. Variabilité du $\mathrm{CO}_{2}$ atmosphérique en régions Australes: comparaison modèle/mesures. Thèse de Doctorat, Université de Paris 7, France.

Ramonet, M., Le Roulley, J. C., Bousquet, P. and Monfray, P. 1996. Radon-222 measurements during the TROPOZ II campaign and comparison with a global atmospheric transport model. J. Atmos. Chem. 23, 107-136.

Simkin, T., Siebert, L., McClelland, L., Bridge, D., Newhall, C. and Latter, J. H. 1981. Volcanoes of the world. Hutchinson Ross Publishing Co., Stroudsburg, 50-65.

Smithsonian Institution. 1992a. Bull. of the Global Volcanism Network 17, 10.

Smithsonian Institution. 1992b. Bull. of the Global Volcanism Network 17, 4.

Turekian, K. K. and Cochran, J. K. $1981 .{ }^{210} \mathrm{~Pb}$ in surface air at Enewetak and the Asian dust flux to the Pacific. Nature 292, 522-524.

Turekian, K. K., Graustein, W. C. and Cochran, J. K. 1989. Lead-210 in the SEREX Program: an Aerosol Tracer Across the Pacific. In: Chemical oceanography, vol. 10, (ed. Riley, J. P. and Chester, R.). Academic Press, London, 51-81.

Turekian, K. K., Nozaki, Y. and Benninger, L. K. 1977. Geochemistry of atmospheric radon and radon products. Annu. Rev. Earth Planet. Sci. 5, 227-255.

Twomey, S. 1977. Atmospheric aerosols. Elsevier, Amsterdam, 149-153.

Volcanological Society of Japan, 1994. Bull. of volcanic eruptions 31, 48-49.

Wilkening, M. H., Clements, W. E. and Stanley, D. 1972. Radon 222 flux measurements in widely separated regions. In: The natural radiation environment (II). $U$. S. Energy and Research Development Administration, Oak Ridge, 713-730.

Winkler, R., Holtz, H. and Chatterjee, B. 1981. Analysis of ${ }^{210} \mathrm{~Pb}$ and ${ }^{210} \mathrm{~Pb}$ concentrations in surface air by an alpha spectrometric method. Health Phys. 41, 495-503. 